\title{
Orthodontic approach in dental trauma: systematic review and meta-analysis
}

\author{
Abordagem ortodôntica em trauma dental: revisão sistemática e meta-análise \\ Enfoque ortodóncico en trauma dental: revisión sistemática y meta-análisis \\ Christine Men MARTINS ${ }^{1}$ \\ Victor Eduardo de Souza BATISTA ${ }^{2}$ \\ Ana Caroline Gonçales VERRI ${ }^{3}$ \\ Fellippo Ramos VERRI ${ }^{2}$ \\ João Eduardo GOMES FILHO 4 \\ Sonia Regina PANZARINI ${ }^{5}$
}

Fundação Municipal de Educação e Cultura FUNEC Santa Fé do Sul-SP, Brazil

${ }^{2}$ Department of Dental Materials and Prosthodontics, São Paulo State University (Unesp), School of Dentistry, Araçatuba - SP, Brazil

${ }^{3}$ Department of Pediatric and Community Dentistry, São Paulo State University (Unesp), School of Dentistry, Araçatuba - SP, Brazil

${ }^{4}$ Department of Restorative Dentistry, São Paulo State University (Unesp), School of Dentistry, Araçatuba - SP, Brazil

${ }^{5}$ Department of Surgery and Integrated Clinic, São Paulo State University (Unesp), School of Dentistry, Araçatuba - SP, Brazil

\begin{abstract}
Introduction: There is a high prevalence of dental trauma in patients in need of orthodontic treatment, so it is important the knowledge about the orthodontic approach in cases of traumatized teeth. Thus, this study conducted a systematic review about orthodontic approach in dental trauma. Materials and Methods: Two investigators performed a systematic review with meta-analysis. MEDLINE/PubMed and Cochrane Library supplied relevant data from studies published between February 2004 and September 2015 on the relationship between dental trauma and orthodontic treatment. Results: Susceptibility to pulp necrosis was the dichotomous outcomes measure evaluated by risk ratio (RR) and the corresponding $95 \%$ confidence intervals (CI). The quality was evaluated using the Oxford Centre for Evidence-Based Medicine (EbM) guidelines. A search strategy and application of eligibility criteria enabled selection and evaluation of four studies on orthodontic treatment in traumatized teeth. In total, 1.696 patients (average age 11.6 years) with orthodontic treatment over 24.2 months were studied, and 484 had already suffered dental trauma and undergone orthodontic treatment. The primary observed sequelae after orthodontic treatment indicated greater susceptibility to pulp necrosis in traumatized teeth compared to no previous trauma. The patients with orthodontically treated traumatized maxillary incisors were more susceptible to pulp necrosis (RR: 7.6 ; 95\% CI: 3.64 to $15.87 ; p=0.00001$ ) compared to patients with previous dental trauma to the maxillary incisors and no subsequent orthodontic treatment. Conclusion: There is no well-established protocol for these cases; such treatment must be careful and respect the healing period post-trauma, when these teeth are more susceptible to pulp necrosis and pulp obliteration.

Descriptors: Tooth Injuries; Wounds and Injuries; Tooth Avulsion; Orthodontics, Corrective.
\end{abstract}

\section{Resumo}

Introdução: Existe uma alta prevalência de trauma dental em pacientes com necessidade de tratamento ortodôntico, sendo importante o conhecimento da abordagem ortodôntica em dentes traumatizados. Assim, este estudo realizou uma revisão sistemática sobre abordagem ortodôntica em trauma dental. Materiais e Métodos: Dois investigadores realizaram uma revisão sistemática com metanálise. MEDLINE / PubMed e Cochrane Library forneceram dados relevantes de estudos publicados entre fevereiro de $2004 \mathrm{e}$ setembro de 2015 sobre a relação entre trauma dental e tratamento ortodôntico. Resultados: A suscetibilidade à necrose pulpar foi a medida de desfecho dicotômico avaliada pela razão de risco (RR) e os correspondentes intervalos de confiança de $95 \%$ (IC). A qualidade foi avaliada utilizando as diretrizes do Oxford Center for Evidence-Based Medicine (EbM). Uma estratégia de busca e aplicação de critérios de elegibilidade permitiram a seleção e avaliação de quatro estudos sobre tratamento ortodôntico em dentes traumatizados. No total, foram estudados 1.696 pacientes (média de idade de 11,6 anos) com tratamento ortodôntico ao longo de 24,2 meses e 484 também sofreram trauma dental e foram submetidos a tratamento ortodôntico. As principais sequelas observadas após o tratamento ortodôntico indicaram maior susceptibilidade à necrose pulpar em dentes traumatizados, em comparação com nenhum trauma prévio. Os pacientes com incisivos maxilares traumatizados tratados ortodonticamente foram mais suscetíveis à necrose pulpar (RR: 7,6; IC 95\%: 3,64 a 15,87; p = 0,00001) em comparação com pacientes com traumatismo dentário anterior aos incisivos maxilares e sem tratamento ortodôntico subsequente. Conclusão: Não há um protocolo bem estabelecido para estes casos; tal tratamento deve ser cuidadoso e respeitar o período de cicatrização pós-trauma, quando estes dentes são mais suscetíveis à necrose pulpar e obliteração da polpa.

Descritores: Traumatismos Dentários; Ferimentos e Lesões; Avulsão Dentária; Ortodontia Corretiva.

\section{Resumen}

Introducción: Existe una alta prevalencia de traumatismos dentales en pacientes con necesidad de tratamiento ortodóncico, por lo que es importante el conocimiento sobre el abordaje ortodóntico en casos de dientes traumatizados. Así, este estudio realizó una revisión sistemática sobre el enfoque ortodóntico en trauma dental. Materiales y Métodos: Dos investigadores realizaron una revisión sistemática con metanálisis. MEDLINE / PubMed y Cochrane Library proporcionaron datos relevantes de estudios publicados entre febrero de 2004 y septiembre de 2015 sobre la relación entre el trauma dental y el tratamiento ortodóncico. Resultados: La susceptibilidad a la necrosis pulpar fue la medida de resultado dicotómica evaluada por la razón de riesgo (RR) y los correspondientes intervalos de confianza (IC) del 95\%. La calidad se evaluó utilizando las directrices del Oxford Centre for Evidence-Based Medicine $(\mathrm{EbM})$. Una estrategia de búsqueda y aplicación de criterios de elegibilidad permitió la selección y evaluación de cuatro estudios sobre el tratamiento ortodóncico en dientes traumatizados. En total, se estudiaron 1.696 pacientes (edad media 11.6 años) con tratamiento ortodóncico durante 24.2 meses y 484 ya habían sufrido traumas dentales y se les había realizado tratamiento ortodóncico. Las principales secuelas observadas después del tratamiento ortodóncico indicaron mayor susceptibilidad a la necrosis pulpar en los dientes traumatizados en comparación con ningún trauma previo. Los pacientes con incisivos maxilares traumatizados tratados ortodónticamente fueron más susceptibles a la necrosis pulpar (RR: 7,6; IC del 95\%: 3,64 a 15,87; p = 0,00001) en comparación con los pacientes con traumatismo dental anterior a los incisivos maxilares y ningún tratamiento ortodóncico posterior. Conclusión: No existen protocolos bien establecidos para estos casos; Dicho tratamiento debe ser cuidadoso y respetar el período de cicatrización postraumático, cuando estos dientes son más susceptibles a la necrosis pulpar ya la obliteración de la pulpa.

Descriptores: Traumatismo de los Dientes; Heridas y Traumatismos; Avulsion de Diente; Ortodoncia Correctiva.

\section{INTRODUCTION}

The high rates of dental caries and periodontal disease and also dental trauma are major public health problems that require the most urgent care in dental or hospital environments ${ }^{1,2}$. In this context, the main etiological factors 
of dental trauma are physical violence; car, motorcycle, or bicycle accidents; and wide participation of people in sports and leisure activities with potential risk of dental trauma without using of mouth guards ${ }^{3,4}$. Furthermore, protrusion of the incisors and consequent lack of marginal sealing lips contribute to an increase in this frequency, 5 .

Young adults, teenagers, and mainly children are affected by dental trauma, especially tooth luxation ${ }^{1,3-6}$. Thus, orthodontic treatment may be coadjutant, preventing dental trauma by the correction of protrusion of the incisors and promotion of the marginal sealing lips ${ }^{7}$.

After the occurrence of dental trauma, the following treatment can be divided didactically in three steps: primary, secondary, and tertiary treatments ${ }^{6}$. Primary treatment is urgent care done during the first care visit. Pulp and periodontal ligament healing and the cicatrization process are expected in secondary treatments, when the containments are placed. Tertiary treatments are related to patient rehabilitation and are multidisciplinary, involving dental and medical areas ${ }^{6}$.

Orthodontic treatment can be performed as part of the three treatment steps. Primary and secondary steps can be performed as orthodontic extrusion due to intrusion luxation or fractures involving the crown and root with invasion of the biological space ${ }^{6}$. The tertiary step involves orthodontic treatment to rehabilitate and restore normal patterns in patients $^{6,8}$. However, the true effect of orthodontic treatment in post-trauma cases has not been established in the literature, and there are no procedure protocols for orthodontists.

Within this context, there is a high prevalence of dental trauma in patients in need of orthodontic treatment ${ }^{9}$. Therefore, the aim of this study was to conduct a systematic review to evaluate the orthodontic approach in dental trauma.

\section{MATERIAL AND METHOD}

\section{○ Register Protocol}

Data extraction was conducted according to the PRISMA checklist ${ }^{10}$ and previously published studies ${ }^{11,12}$. Initially, this study was registered on the international prospective register of systematic reviews (PROSPERO) (CRD42014014347).

\section{○ Eligibility Criteria}

The inclusion criteria were (a) the comparison of orthodontic treatment in patients with and without previous dental trauma; (b) orthodontic treatment in the tertiary step of trauma treatment; (c) in the absence of randomized controlled trials (RCT), prospective and retrospective trials was selected; and (d) studies in English language.

Exclusion criteria were (a) studies that evaluated the orthodontic treatment in the secondary step of trauma treatment; (b) studies that described esthetic corrective orthodontic treatment for tooth lost due avulsion; (c) systematic reviews and literature reviews, in vitro and in vivo studies, letter to editor and clinical cases; and (d) studies without available abstracts.

The PICO question was structured as follows: How much time is necessary to conduct orthodontic treatment in patients who have suffered dental trauma? In which: $(\mathrm{P})$ patients who have suffered dental trauma, (I) patients who have suffered dental trauma before or during orthodontic treatment, (C) patients who have performed orthodontic treatment without previous dental trauma and/or patients who have suffered dental trauma and do not do orthodontic treatment, and $(\mathrm{O})$ patients with possible injuries to the dental pulp.

\section{○ Information Sources}

PubMed/Medline and Cochrane Library databases were conducted to find articles published between February 2004 and June 2015. In addition, a manual search from May 2004 to September 2015 was conducted in the following periodicals: Dental Traumatology, American Journal of Orthodontics and Dentofacial Orthopedics, Journal of Orthopaedic Research, The Angle Orthodontist, Orthodontics \& Craniofacial Research, and European journal of orthodontics. It was not necessary to contact the author to identify additional studies.

○ Search Strategy

Two individuals (CMM and VESB) performed the electronic search in the databases individually. The keywords used for the search were "tooth injuries" and "orthodontics corrective"; "orthodontic corrective" and "dental trauma"; and "orthodontic treatment" and "dental trauma". Search details were as follows: "tooth injuries"[MeSH Terms] OR ("tooth"[All Fields] AND “injuries"[All Fields]) OR "tooth injuries"[All Fields]) AND ("orthodontics"[MeSH Terms] OR “orthodontics"[All Fields]) AND Corrective[All Fields]; orthodontic[All Fields] AND corrective[All Fields] AND ("dental clinics"[MeSH Terms] OR ("dental"[All Fields] AND "clinics"[All Fields]) OR “dental clinics"[All Fields] OR "dental”[All Fields]) AND ("injuries"[Subheading] OR "injuries"[All Fields] OR "trauma"[All Fields] OR "wounds and injuries" [MeSH Terms] OR ("wounds"[All Fields] AND "injuries"[All Fields]) OR "wounds and injuries"[All Fields]);Orthodontic[All Fields] AND ("therapy"[Subheading] OR "therapy"[All Fields] OR "treatment"[All Fields] OR "therapeutics"[MeSH Terms] OR "therapeutics"[All Fields]) AND ("dental clinics"[MeSH Terms] OR (“dental”[All Fields] AND “clinics"[All Fields]) OR “dental clinics"[All Fields] OR "dental"[All Fields]) AND ("injuries"[Subheading] OR "injuries"[All Fields] OR "trauma"[All Fields] OR "wounds and injuries" [MeSH Terms] OR ("wounds"[All Fields] AND "injuries"[All Fields]) OR “wounds and injuries"[All Fields]).

○ Studies Selection

In the first stage of the selection process, two observers (CMM and VESB) independently selected articles based on title and abstract, in accordance with the eligibility criteria. After reviewing the titles and abstracts, articles were classified as either included or excluded. Any disagreements were resolved by discussion and consensus. In the second stage, the sampled articles were read, and a manual search was conducted in the reference list.

\section{- Data Extraction}

One author (VESB) collected relevant information from selected articles: author, year of study, the research groups studied, number of patients and number of injured teeth, type of injury and number of teeth, orthodontic protocol in traumatized teeth, and applied force and outcome. Then, the second author (CMM) checked the extracted data, along with a third author (ACGV), and orthodontic specialist. Any disagreements were resolved by discussion and consensus.

\section{$\circ$ Risk of Bias}

Observational studies and clinical trials without detailed randomization protocols were considered studies with high risk of bias. To evaluate the quality of each study, we used the guidelines of the Oxford Centre for Evidence- 
Based Medicine (EbM).

\section{- Summary Measures}

The meta-analysis was based on the Mantel-Haenszel method. Susceptibility to pulp necrosis was the dichotomous outcomes measure evaluated by risk ratio (RR) and the corresponding $95 \%$ confidence intervals (CI). The software Reviewer Manager 5 (Cochrane Group) was used on the meta-analysis and to elaborate the funnel plot. Values were considered significant when $p<0.05$.

\section{$\circ$ Bias Risk among the Studies}

Asymmetry of the funnel plot may indicate publication bias and other biases related to sample size, although the asymmetry may also show a true relationship between trial size and effect size. The heterogeneity was assessed using the method $\mathrm{Q}\left(\mathrm{x}^{2}\right)$ and value of $\mathrm{I}^{2}$. The $\mathrm{I}^{2}$ statistic was used to express the percentage of the total variation across studies due to heterogeneity. The fixed effects model was used when there was a low level of heterogeneity between studies.

○ Additional Analysis

The kappa statistic was calculated to define interrater agreement for the process of inclusion of the publications in this systematic review. According to Landis and Koch ${ }^{13}$, the level of interrater agreement is almost perfect if the value of Kappa $(\mathrm{K})$ is $0.81-1.00$, substantial if $\mathrm{K}$ is $0.61-0.80$, moderate if $\mathrm{K}$ is $0.41-0.60$, fair if $\mathrm{K}$ is $0.21-0.40$, and poor if $\mathrm{K}$ is $<0.20$.

\section{RESULT}

\section{○ Study Selection and Characteristics}

A total of 1,344 articles were retrieved, of which only 4 fulfilled eligibility criteria (inter-reader agreement, Kappa $=0.95$ for PubMed/Medline and Kappa $=1$ for Cochrane Library). All studies are retrospectives ${ }^{8,14-16}$. Extracted data are summarized in Table 1.

Table 1. Extracted data

\begin{tabular}{|c|c|c|c|c|c|c|c|}
\hline Author & Year & Groups Studied & $\begin{array}{c}\mathrm{N}^{\mathrm{o}} \text { patients / } \\
\mathrm{N}^{\mathrm{o}} \text { traumatized } \\
\text { teeth }\end{array}$ & $\begin{array}{l}\text { Trauma type }{ }^{\S} / \\
\text { No teeth }^{\circ}\end{array}$ & $\begin{array}{l}\text { Orthodontic protocol in } \\
\text { traumatized teeth }\end{array}$ & $\begin{array}{l}\text { Applied } \\
\text { force }\end{array}$ & Outcome \\
\hline Bauss et al. ${ }^{15}$ & 2008 & $\begin{array}{c}\text { G1 - Patients with } \\
\text { orthodontically treated } \\
\text { traumatized maxillary } \\
\text { incisors (orthodontic } \\
\text { intrusion) } \\
\text { G2 - Patients with previous } \\
\text { dental trauma to the } \\
\text { maxillary incisors and no } \\
\text { subsequent orthodontic } \\
\text { treatment }\end{array}$ & G2-173/193 & $\begin{array}{c}\text { G1- Crown } \\
\text { fractures:151 } \\
\text { Subluxation: } 31 \\
\text { Lateral luxation: } 30 \\
\text { Extrusive luxation: } 28 \\
\text { Intrusive luxation: } 29 \\
\text { G2- Crown } \\
\text { fractures:68 } \\
\text { Subluxation: } 31 \\
\text { Lateral luxation: } 33 \\
\text { Extrusive luxation: } 30 \\
\text { Intrusive luxation: } 31\end{array}$ & $\begin{array}{l}\text { G1- Orthodontic treatment of } \\
\text { the previously traumatized } \\
\text { teeth had been started at the } \\
\text { earliest } 3 \text { months after hard- } \\
\text { tissue injuries and } 12 \text { months } \\
\text { after periodontal tissue } \\
\text { injuries }\end{array}$ & $\begin{array}{l}\text { 15g per } \\
\text { tooth }\end{array}$ & $\begin{array}{c}\text { Orthodontic } \\
\text { intrusion of } \\
\text { traumatized teeth } \\
\text { with total pulp } \\
\text { obliteration showed a } \\
\text { higher susceptibility } \\
\text { to pulpal } \\
\text { complications during } \\
\text { orthodontic intrusion } \\
\text { compared to } \\
\text { traumatized teeth } \\
\text { without or only } \\
\text { partial pulp } \\
\text { obliteration. }\end{array}$ \\
\hline Bauss et al. ${ }^{14}$ & 2008 & $\begin{array}{c}\text { G1- Patients with } \\
\text { orthodontically treated } \\
\text { trauma tized maxillary } \\
\text { incisors (orthodontic } \\
\text { intrusion) } \\
\text { G2- orthodontically treated } \\
\text { patients with } \\
\text { nontraumatized maxillary } \\
\text { incisors (orthodontic } \\
\text { intrusion) } \\
\text { G3- patients with previous } \\
\text { dental trauma to the } \\
\text { maxillary incisors and no } \\
\text { subsequent orthodontic } \\
\text { treatment }\end{array}$ & $\begin{array}{l}\mathrm{G} 1-186 / 269 \\
\mathrm{G} 2-200 /(-) \\
\text { G3-173/193 }\end{array}$ & $\begin{array}{c}\text { G1 - Crown fractures: } \\
151 \\
\text { Subluxation: } 31 \\
\text { Lateral luxation: } 30 \\
\text { Extrusive luxation: } 28 \\
\text { Intrusive luxation : } 29 \\
\text { G2- (-) } \\
\text { G3- Crown fractures: } \\
68 \\
\text { Subluxation: } 31 \\
\text { Lateral luxation: } 33 \\
\text { Extrusive luxation: } 30 \\
\text { Intrusive luxation : } 31\end{array}$ & $\begin{array}{l}\text { G1- orthodontic treatment } \\
\text { had begun not earlier than } 3 \\
\text { months after hard-tissue } \\
\text { injuries or subluxation, and } \\
\text { not earlier than } 12 \text { months } \\
\text { after severe periodontal } \\
\text { injuries (lateral, extrusive, or } \\
\text { intrusive luxation) }\end{array}$ & $\begin{array}{l}\text { 15g per } \\
\text { tooth }\end{array}$ & $\begin{array}{c}\text { Previously } \\
\text { traumatized } \\
\text { maxillary incisors, } \\
\text { and especially } \\
\text { lateral incisors, with } \\
\text { severe periodontal } \\
\text { injuries have higher } \\
\text { susceptibility to } \\
\text { pulp necrosis } \\
\text { during orthodontic } \\
\text { intrusion compared } \\
\text { to nontraumatized } \\
\text { teeth. }\end{array}$ \\
\hline Bauss et al. ${ }^{16}$ & 2009 & $\begin{array}{l}\text { G1-Patients suffering dental } \\
\text { trauma during orthodontic } \\
\text { treatment } \\
\text { G2- Orthodontically treated } \\
\text { patients without dental } \\
\text { trauma } \\
\text { G3- patients with previous } \\
\text { dental trauma to the } \\
\text { maxillary incisors and no } \\
\text { subsequent orthodontic } \\
\text { treatment }\end{array}$ & $\begin{array}{c}\mathrm{G} 1-46 / 59 \\
\text { G2- 200/ (-) }\end{array}$ & $\begin{array}{c}\text { G1- Crown fractures: } \\
28 \\
\text { Subluxation: } 8 \\
\text { Lateral luxation or } \\
\text { extrusive luxation:11 } \\
\text { Intrusive luxation: } 12 \\
\text { G2- (-) } \\
\text { G3- Crown fractures : } \\
\text { 68; } \\
\text { Subluxation: } 31 \\
\text { Lateral luxation: } 33 \\
\text { Extrusive luxation: } 30 \\
\text { Intrusive luxation : } 31\end{array}$ & $\begin{array}{l}\text { G1- In cases of hard tissue } \\
\text { (fracture of enamel and fracture } \\
\text { of enamel-dentin) or slight } \\
\text { periodontal injury (subluxation), } \\
\text { orthodontic movement of the } \\
\text { traumatized teeth was } \\
\text { interrupted for } 2 \text { to } 3 \text { months. In } \\
\text { cases with extrusive or lateral } \\
\text { luxations, the traumatized teeth } \\
\text { and associated fractures of the } \\
\text { socket wall were repositioned } \\
\text { carefully, and fixation was } \\
\text { performed by stainless steel } \\
\text { wire. This connected the } \\
\text { traumatized tooth with both } \\
\text { adjacent teeth and was left for } 3 \\
\text { weeks. In all cases with severe } \\
\text { periodontal injury, orthodontic } \\
\text { movement was interrupted for } 5 \\
\text { to } 6 \text { months }\end{array}$ & G1- (-) & $\begin{array}{l}\text { Teeth with severe } \\
\text { periodontal injury } \\
\text { during orthodontic } \\
\text { therapy and } \\
\text { subsequent total } \\
\text { pulp obliteration } \\
\text { have an increased } \\
\text { risk of pulp necrosis } \\
\text { during later } \\
\text { orthodontic } \\
\text { treatment stages. }\end{array}$ \\
\hline Bauss et al. ${ }^{8}$ & 2010 & $\begin{array}{l}\text { G1- Orthodontically treated } \\
\text { patients with traumatized } \\
\text { maxillary incisors (extrusion } \\
\text { orthodontic) } \\
\text { G2-orthodontically treated } \\
\text { patients } \\
\text { nontraumatized with } \\
\text { maxillaryincisors (extrusion } \\
\text { orthodontic) } \\
\text { G3-patients with previous } \\
\text { dental trauma to the } \\
\text { maxillary incisors and no } \\
\text { subsequent orthodontic } \\
\text { treatment }\end{array}$ & $\begin{array}{l}\text { G1- 66/77 } \\
\text { G2-100/(-) } \\
\text { G3-173/193 }\end{array}$ & $\begin{array}{c}\text { G1- Crown fractures: } \\
32 \\
\text { Subluxation, lateral } \\
\text { luxation, extrusive } \\
\text { luxation and intrusive } \\
\text { luxation : } 45 \\
\text { G2- (-) } \\
\text { G3- Crown fractures: } \\
68 \\
\text { Subluxation, lateral } \\
\text { luxation, extrusive } \\
\text { luxation and intrusive } \\
\text { luxation:125 }\end{array}$ & $\begin{array}{l}\text { G1- orthodontic treatment } \\
\text { was initiated at the earliest } 3 \\
\text { months after hard tissue } \\
\text { injuries or subluxation and } \\
12 \text { months after severe } \\
\text { periodontal tissue injuries } \\
\text { (lateral, extrusive, or } \\
\text { intrusive luxation) }\end{array}$ & $\begin{array}{l}20 g \text { per } \\
\text { tooth }\end{array}$ & $\begin{array}{l}\text { Maxillary incisors } \\
\text { with a history of } \\
\text { trauma and severe } \\
\text { periodontal tissue } \\
\text { injuries have a } \\
\text { higher susceptibility } \\
\text { to pulp necrosis } \\
\text { during orthodontic } \\
\text { extrusion than do } \\
\text { non traumatized } \\
\text { teeth. }\end{array}$ \\
\hline
\end{tabular}




\section{○ Qualitative Analysis}

A total of 1,696 patients with an average age of 11.6 years with orthodontic treatment over 24.2 months were included, and 484 had already suffered dental trauma and had had orthodontic treatment.

The type of malocclusion is not elucidated in all studies. In research conducted by Bauss et al. ${ }^{8}$, the patients had an anterior open bite. However, in another study, Bauss et al. ${ }^{16}$ did not specify the type of malocclusion in patients. Malocclusion class II, division 1, and overbite were cited by Bauss et al. ${ }^{15}$ only in group 1 patients. The same type of malocclusion was described by Bauss et al. ${ }^{14}$ in groups 1 and 2 ; however, group 3 did not show the type of malocclusion.

A total of 1,446 central and lateral incisors were traumatized, and 634 of these teeth had injuries to the bones and pulp tissue, and 812 had injuries to periodontal tissue. The mean age was 9.4 years.

- Orthodontic Protocol in Traumatized Teeth

A fixed orthodontic appliance with preadjusted brackets of 0.018 " slots was used in all selected studies. Bauss et al. ${ }^{8}$ used a $0.016 " \times$ x $0.016 "$ Elgiloy $^{\circledR}$ (Rocky Mountain Orthodontics, Denver, CO) blue extrusion arch from the maxillary tube of the maxillary right first molar to the maxillary left first molar.

Bauss et al. $^{16}$ performed an initial orthodontic treatment specific to the type of trauma. Teeth that suffered extrusive and lateral luxation were repositioned and fixed with wire thickness of 0.016 " x 0.022 " over 3 weeks. In cases of intrusive luxation, they waited 3 or 4 weeks for the occurrence of spontaneous eruption. If this eruption did not occur, orthodontic extrusion using elastic fixed on 0.016 " $\mathrm{x}$ 0.022 " wire for 3 or 4 weeks was used.

The sequence of orthodontic wires for dental alignment and leveling was the same in all cases. Bauss et al. ${ }^{14-15}$ used an Elgiloy ${ }^{\circledR}$ wire thickness of 0.016 " $\mathrm{x} 0.016$ " to perform the orthodontic intrusion, extending from the upper first molar on one side to the first molar on the opposite side. Interference of canines and premolars was prevented by second-order folds contouring these teeth. Treatment intrusion was performed to correct the vertical problem. Thereafter, continuous arches and elastics to Class II orthodontic finishing were used. The orthodontic protocol for traumatized teeth for each study can be seen in Table 1 .

- Sequelae after Orthodontic Treatment in Patients with Previous Trauma

The major sequelae observed in these 484 traumatized patients after orthodontic treatment was greater susceptibility to pulp necrosis in traumatized teeth compared to teeth with no previous trauma (Table 1). Moreover, partial obliteration and total pulp obliteration were related.

\section{○ Assessment of Study Quality}

Data concerning the type of study and level of scientific evidence may be seen in Table 2 . No randomized controlled studies were found.

○ Meta-Analysis

The meta-analysis of three studies with respect to pulp necrosis was performed ${ }^{8,14,16}$. These studies showed a group of patients with orthodontically treated traumatized maxillary incisors compared to patients with previous dental trauma to the maxillary incisors and no subsequent orthodontic treatment. A weighted average across the studies was provided according to a fixed-effect model, and it indicated a statistical difference in pulp necrosis (RR: 7.6; 95\% CI: 3.64 to $15.87 ; p=0.00001)$; the group of patients with orthodontically treated traumatized maxillary incisors was more susceptible to pulp necrosis (Figure 1). Furthermore, the heterogeneity intra-studies were of $x^{2}: 0.71$ and heterogeneity inter-studies were of $\mathrm{I}^{2}: 0$. The funnel plot showed an evident symmetry among the difference of means of the studies evaluated (Figure 2).

Table 2. Quality of each study

\begin{tabular}{lccc}
\hline Study & Year & Study Design & Evidence Level* \\
\hline Bauss et al. ${ }^{\text {* }}$ & 2008 & Retrospective cohort & IV \\
Bauss et al.14 & 2008 & Retrospective cohort & \\
Bauss et al. ${ }^{16}$ & 2009 & study & IV \\
& & Retrospective cohort & IV \\
Bauss et al. ${ }^{8}$ & 2010 & Retudy & IV \\
& & study &
\end{tabular}

\footnotetext{
*Oxford Centre for Evidence-Based Medicine 2011 Levels of Evidence.
}

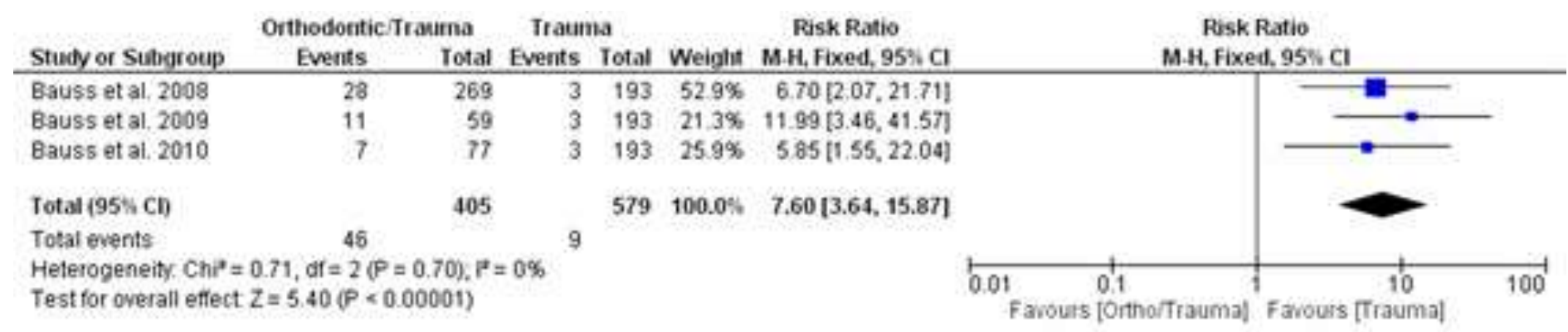

Figure 1. Forest plot; comparison of studies evaluating the pulp necrosis. 


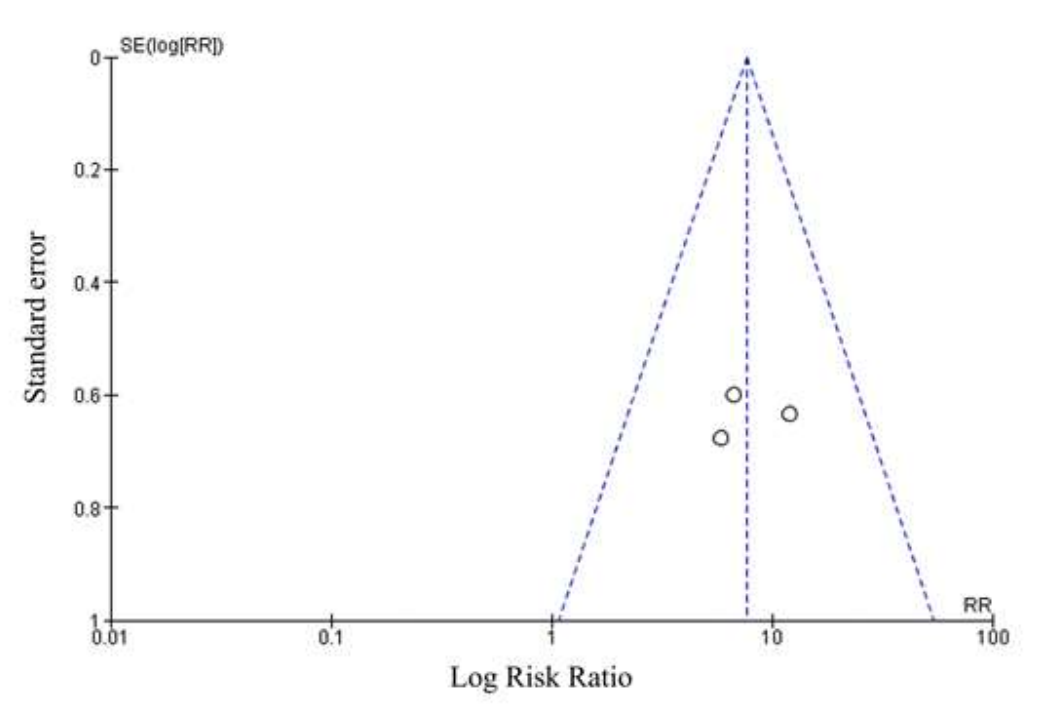

Figure 2. Funnel plot to evaluate the risk of bias.

\section{DISCUSSION}

Many patients requiring or are who are undergoing orthodontic treatments can suffer dental trauma,16 Therefore knowledge and elucidation by orthodontists about trauma types, the healing process, and the interference of orthodontic treatment are necessary.

Dental trauma often affects children, teenagers, and young adults ${ }^{1,3-6}$, and certain age groups are capable of initiating interceptive and/or corrective orthodontic treatment because orthodontic and orthopedic treatment is indicated when the person is at the stage of pubertal growth to correct or reduce the complexity of malocclusion of skeletal origin when in permanent dentition ${ }^{17}$.

Orthodontic treatment in patients who have suffered dental trauma can make these teeth more susceptible to external root resorption ${ }^{18}$ and pulp necrosis ${ }^{8,9,14-16}$. Although the selected studies did not mention external root resorption, it can occur, depending on type and intensity of trauma ${ }^{8,14-16}$. Thus, knowledge of orthodontic approach in dental trauma is extremely important to planning and to having success in orthodontic treatment.

More severe dental trauma can lead to associated injuries of the periodontal ligaments supporting dental tissues, bone, and pulp ${ }^{19}$. Most of dental trauma in selected studies affected supporting dental tissues and pulp ${ }^{8,14-16}$. However, the studies also described periodontal ligament injuries that lead to sequels, especially external root resorption due to periodontal ligament lesion and pulp necrosis.

Depending on the type and intensity of dental trauma, some areas of periodontal ligaments can mortify, and during the healing process, these areas can be colonized by bone cells $^{20}$. The initiation of an inflammatory process-for example, due to orthodontic movement-can initiate external root resorption because these bone cells have receptors for these mediators of inflammation and may provide basic multicellular units (BMU) that will initiate the tooth resorption ${ }^{18,20}$ This demonstrates the importance of care in orthodontic movement after dental trauma.

Another common sequel that may be compounded due to orthodontic movement is pulp necrosis ${ }^{14-16}$. Depending on the stage of root formation and the dental trauma intensity, the pulp healing process can include three different paths: (a) revascularization, (b) hard tissue formation (which can lead to partial or complete obliteration of the root canal), or (c) pulp necrosis ${ }^{18}$. Extrusive, lateral, and intrusive luxation and avulsion have a greater chance of leading to pulp necrosis after dental trauma, especially in teeth with complete root formation due to the rupture of the vascular-nerve bundle that nourishes the pulp ${ }^{18}$. The relation between teeth with necrosis and without necrosis in teeth treated orthodontically after an injury varies from 10 to $18 \%{ }^{8,14,15}$. In teeth orthodontically treated without trauma the relation is 0.3 to $0.5 \%$ and in teeth treated only for a trauma the relation is $1.6 \%$. Chi-square analyses show significant differences in the number of teeth with necrosis if the patient had sustained a trauma before orthodontic treatment or if they had no trauma.

None of the selected studies have reported difficulty in orthodontic movement in traumatized patients ${ }^{8,14-16}$. The increase in the obliteration of the root canal due to dental trauma was reported by the studies when orthodontic movement was performed ${ }^{21-23}$. Mild orthodontic forces should be used on teeth that have suffered trauma to prevent external root resorption ${ }^{23}$. Furthermore, the intensity and duration must also be taken into account ${ }^{24}$. Heavy and continuous forces may aggravate and increase the risk of resorption $^{25}$. In addition, other factors such as the type of orthodontic movement and thickness existing between the cortical bone and the root may influence the predisposition to resorption. Therefore, the use of less intense forces than normal is indicated. Studies suggest that force should not exceed $20 \mathrm{~g}^{26,27}$, which corroborates with data of studies evaluated in this review ${ }^{8,14,16}$.

Integral to orthodontic treatment success after dental trauma is respect for the healing process ${ }^{18}$. In most of the selected studies, the waiting period after dental trauma to start orthodontic treatment was, on average, 3 months for subluxation and 12 months for extrusive, lateral, and intrusive luxation $^{8,14,15}$. The clinical and radiographic followup should be performed carefully because the possibility of pulp necrosis is great, and once detected, endodontic treatment should be instituted immediately. Studies show that other waiting periods are necessary to decrease sequelae on dental pulp.

In this study, most research involved braces, bands, and brackets ${ }^{8,14,16}$. The use of braces is considered an effective form of treatment to generate better control of tooth movement and does not require the patient's cooperation ${ }^{28}$. In this context, studies that assess the influence of force in sequelae on dental pulp need be performed.

These studies may show the behavior of traumatized teeth under orthodontic treatment besides serving as a foundation for systematic reviews in the future. However, we had difficulty in conducting this review because of the lack of articles, wherein in the four studies analyzed the material collected can be from the same cohort of patients. Thereby, we encourage performing retrospectives studies and randomized clinical studies in order to establish the safest protocols to guide orthodontic treatment after dental trauma.

\section{CONCLUSION}

Many patients who suffer dental trauma need orthodontic treatment. The literature does not demonstrate a well-established protocol for orthodontic treatment in patients who have suffered dental trauma, but this treatment must be conducted carefully and respect the healing period post-trauma, when these teeth are more susceptible to pulp necrosis and pulp obliteration.

\section{REFERENCES}

1. Bastone EB, Freer TJ, McNamara JR. Epidemiology of dental trauma. A review of the literature. Aust Dent $\mathrm{J}$. 2000 Mar;45(1):2-9. 
2. Caldas AF Jr, Burgos ME. A retrospective study of traumatic dental injuries in a brazilian dental trauma clinic. Dent Traumatol. 2001 Dec;17(6):250-3.

3. Cioata R, Savin C, Vataman M, Maxim A, Balan A. Considerations on the epidemiology, etiology and profile of periodontal--dental injuries in preschool population in iasi county. Rev Med Chir Soc Med Nat Iasi. 2013 Jan-Mar;117(1):222-6.

4. Toprak ME, Tuna EB, Seymen F, Gencay K. Traumatic dental injuries in turkish children, istanbul. Dent Traumatol. 2014 Aug;30(4):280-4.

5. Siqueira MB, Gomes MC, Oliveira AC, Martins CC, Granville-Garcia AF, Paiva SM. Predisposing factors for traumatic dental injury in primary teeth and seeking of post-trauma care. Braz Dent J. 2013 NovDec;24(6):647-54.

6. Fields HW, Christensen JR. Orthodontic procedures after trauma. J Endod. 2013 Mar;39(3 Suppl):S78-87.

7. Kindelan SA, Day PF, Kindelan JD, Spencer JR, Duggal MS. Dental trauma: An overview of its influence on the management of orthodontic treatment. Part 1. J Orthod. 2008 Jun;35(2):68-78.

8. Bauss O, Schafer W, Sadat-Khonsari R, Knosel M. Influence of orthodontic extrusion on pulpal vitality of traumatized maxillary incisors. J Endod. 2010 Feb;36(2):203-7.

9. Bauss O, Rohling J, Schwestka-Polly R. Prevalence of traumatic injuries to the permanent incisors in candidates for orthodontic treatment. Dent Traumatol. 2004 Apr;20(2):61-6.

10. Moher D, Shamseer L, Clarke M, Ghersi D, Liberati A, Petticrew M, Shekelle P, Stewart LA; PRISMA-P Group. Preferred reporting items for systematic review and meta-analysis protocols (PRISMA-P) 2015 statement. Syst Rev. 2015 Jan 1;4:1.

11. de Souza Batista VE, Junior JF, de Faria Almeida DA, de Toledo Piza Lopes LF, Verri FR, Pellizzer EP. The effect of offset implant configuration on bone stress distribution: A systematic review. J Prosthodont. 2015 Feb;24(2):93-9.

12. Lopes LF, da Silva VF, Santiago JF, Jr., Panzarini SR, Pellizzer EP. Placement of dental implants in the maxillary tuberosity: A systematic review. Int $\mathrm{J}$ Oral Maxillofac Surg. 2015 Feb;44(2):229-38.

13. Landis JR, Koch GG. The measurement of observer agreement for categorical data. Biometrics. 1977 Mar;33(1):159-74.

14. Bauss O, Rohling J, Sadat-Khonsari R, Kiliaridis S. Influence of orthodontic intrusion on pulpal vitality of previously traumatized maxillary permanent incisors. Am J Orthod Dentofacial Orthop. 2008 Jul;134(1):12-7.

15. Bauss O, Rohling J, Rahman A, Kiliaridis S. The effect of pulp obliteration on pulpal vitality of orthodontically intruded traumatized teeth. J Endod. 2008 Apr;34(4):417-20.

16. Bauss O, Rohling J, Meyer K, Kiliaridis S. Pulp vitality in teeth suffering trauma during orthodontic therapy. Angle Orthod. 2009 Jan;79(1):166-71.

17. Dimberg L, Arnrup K, Bondemark L. The impact of malocclusion on the quality of life among children and adolescents: A systematic review of quantitative studies. Eur J Orthod. 2015 Jun;37(3):238-47.

18. Andreasen JO, Bakland LK, Andreasen FM. Traumatic intrusion of permanent teeth. Part 3. A clinical study of the effect of treatment variables such as treatment delay, method of repositioning, type of splint, length of splinting and antibiotics on 140 teeth. Dent Traumatol. 2006 Apr;22(2):99-111.

19. Andreasen JO, Lauridsen E, Gerds TA, Ahrensburg SS Dental trauma guide: A source of evidence-based treatment guidelines for dental trauma. Dent Traumatol. 2012 Apr;28(2):142-7.

20. Consolaro A. The four mechanisms of dental resorption initiation. Dental Press J Orthod. 2013 May-Jun;18(3):79.

21. Mostafa YA, Iskander KG, El-Mangoury NH. Iatrogenic pulpal reactions to orthodontic extrusion. Am J Orthod Dentofacial Orthop. 1991 Jan;99(1):30-4.

22. McDonald F, Pitt Ford TR. Blood flow changes in permanent maxillary canines during retraction. Eur J Orthod. 1994 Feb;16(1):1-9.

23. Sonmez H, Tunc ES, Dalci ON, Saroglu I. Orthodontic extrusion of a traumatically intruded permanent incisor: A case report with a 5-year follow up. Dent Traumatol. 2008 Dec;24(6):691-4.

24. Krishnan V, Davidovitch Z. Cellular, molecular, and tissue-level reactions to orthodontic force. Am J Orthod Dentofacial Orthop. 2006 Apr;129(4):469.e1-32.

25. Owman-Moll P, Kurol J, Lundgren D. Effects of a doubled orthodontic force magnitude on tooth movement and root resorptions. An inter-individual study in adolescents. Eur J Orthod. 1996 Apr;18(2):14150

26. Jang KT, Kim JW, Lee SH, Kim CC, Hahn SH, GarciaGodoy F. Reposition of intruded permanent incisor by a combination of surgical and orthodontic approach: A case report. J Clin Pediatr Dent. 2002 Summer;26(4):341-5.

27. Kalwitzki M, Weiger R. An intrusion injury as an example of interdisciplinary aspects in dental traumatology: A case report. Quintessence Int. 2005 Mar;36(3):234-42.

28. Medeiros RB, Mucha JN. Immediate vs late orthodontic extrusion of traumatically intruded teeth. Dent Traumatol. 2009 Aug;25(4):380-5.

\section{CONFLICTS OF INTERESTS}

The authors declare no conflicts of interests.

\section{CORRESPONDING AUTHOR}

\section{Christine Men Martins}

christinemen@hotmail.com
Received 29/09/2016 Accepted 13/10/2016 